\title{
Identification of organic pollutants of water in sources of water supply (on the example of the astrakhan region)
}

\author{
${\text { Liudmila } \text { Boronina }^{1 *} \text {, Arkadiy Sokolsky }}^{1}$, and Lev Fesenko ${ }^{2}$ \\ ${ }^{1}$ Astrakhan State University of Architecture and Civil Engineering, 414056, 18 Tatishcheva, St., \\ Astrakhan, Russia \\ ${ }^{2}$ Platov South-Russian State Polytechnic University (NPI), 346428, 132, Prosveshcheniya St., \\ Novocherkassk, Russia
}

\begin{abstract}
In today's diverse world, one of the most urgent tasks is environmental protection, rational use and reproduction of natural resources, conservation of biological diversity. The problem of clean water is one of the most important places in the solution of this problem because surface waters are the most sensitive natural environment link. Without careful monitoring of the state indicated by the latter, it is impossible to prevent the occurrence of adverse environmental situations, maintain the health of the nation and ensure the quality of life. Based on the results of the analysis of indicators of the quality of the water source, the required volumes of water for the consumer and the requirements of the consumer for the produced water, a decision is made on the technology for purifying the required water. Special climatic conditions (sharply continental climate, high summer temperatures, low water levels, etc.) negatively affect the quality indicators of the water source. The article presents the results of a study of surface water by microbiological indicators and phytoplankton. Water was investigated in the area of the channel-type surface water intake structure located in the Astrakhan region on the Volga. It is revealed that the river belongs to the category of dirty. Moreover, there is a positive trend in the development of this process. Applied water treatment technologies are not able to fulfill the tasks to ensure a safe drinking regime. It is known that chlorination of water during water treatment does not affect the removal of metabolites secreted by massively developing species of cyanobacteria (blue-green algae). The authors made recommendations for improving water treatment facilities.
\end{abstract}

\section{Introduction}

Water resources of Russia (underground and surface sources) make up more than $20 \%$ of the world's freshwater reserves [1]. The annual river flow of 2.9 million rivers reaches 4262 $\mathrm{km}^{3}$. The total intake of fresh water from natural sources is about $88 \mathrm{~km}^{3}$ or $2.1 \%$ of total resources. Of this volume $13.6 \mathrm{~km}^{3}$ are groundwater. Almost all water sources, both surface

\footnotetext{
* Corresponding author: boroninalv@gmail.com
} 
and underground, are exposed not only to anthropogenic and technogenic impact with varying degrees of intensity, but are also affected by natural factors. As sources of water supply, water resources must meet stringent hygiene requirements.

According to modern concepts, the main negative effect of water on health is due to the presence of harmful impurities of a chemical and biological nature in it. Excess or deficiency of many chemicals, natural toxins present in water have a negative effect on health. Biological factors are characterized by the presence of pathogenic bacteria, viruses, and protozoa in the water.

The Astrakhan region is located in the southeast of the East European Plain within the Caspian Lowland, in temperate latitudes, in the desert and semi-desert zone. The main landscape of the region is represented by a gently undulating desert plain complicated by huge massifs of bumps, sands, dry hollows, lakes, karst landforms, etc. The current absolute elevation of the Caspian Sea is located at a level of $27 \mathrm{~m}$ below sea level.

The floodplain-delta plain, related to the accumulative plain, is located within the Volga-Akhtuba floodplain and the Volga delta. The right bank of the Volga is steep, actively washed by the waters, is destroyed during floods, the left is gentle, smoothly passes into the island surface of the floodplain. As we move to the south flood plain turns into the delta. The relief of the floodplain-delta part is very dynamic, undergoes certain changes annually: some small rivers die as a result of shallowing, others arise; the shape of the coast, islands

According to climatic conditions, the Astrakhan region represents the driest part of the European territory of Russia. The territory of the region is influenced by the continental air masses of the Siberian anticyclone, the cold air of the Arctic Ocean, the sea air masses of the Atlantic and warm tropical masses. During the winter months, the territory of the region is exposed to the Siberian anticyclone, which greatly cools the land. Atlantic anticyclones have an effect in the summer, warming the land very much and bringing low rainfall.

The sharply continental climate in the region with thermal instability of the evaporation regime of water bodies is an unfavorable environmental factor.

The surface waters of the Astrakhan region are represented by the Volga River with numerous watercourses (about 900), fresh and salty bodies of water (about 1000) and the northern part of the Caspian Sea (Fig. 1). The total length of the coastline of water bodies in the Astrakhan region is $18794.5 \mathrm{~km}$, including rivers - $13984.5 \mathrm{~km}$, lakes - $145 \mathrm{~km}$, ilmenite $-4570 \mathrm{~km}$. Permanent water bodies occupy more than $2000 \mathrm{~km}^{2}$.

In the territory of the Astrakhan region, the Volga in the arid climate does not accept a single tributary, its length within the Astrakhan region is more than $500 \mathrm{~km}$. The speed of the water flow in large ducts ranges from $0.8-1.5 \mathrm{~m} / \mathrm{s}$, In the flood $-2-2.5 \mathrm{~m} / \mathrm{s}$.

Near the city of Volzhsky, the Volgograd region, a large arm separates from the Volga Akhtuba, which forms a vast Volga-Akhtuba floodplain, $450 \mathrm{~km}$ long, with an area of 7500 $\mathrm{km}^{2}$.

The Volga Delta begins at the place of separation of the Buzan arm from the Volga channel The Volga Delta begins at the point of separation of the Buzan arm (46 km north of Astrakhan) from the Volga channel and is one of the largest deltas in Russia and Europe covers an area of $11,000 \mathrm{~km}^{2}$. The delta has up to 500 branches, ducts, and small rivers.

The basis of the delta hydrological network is formed by ducts - shallow watercourses up to 30 meters wide. When flowing into the Caspian, the Volga has about 800 estuaries. To the south of the maritime edge of the delta is a vast fore-delta - a shallow Volga coast. The prevailing depths on it are $1.5 \mathrm{~m}$, increasing during the flood period to $2 \mathrm{~m}$ and falling in the autumn low water to $1 \mathrm{~m}$ or less. 


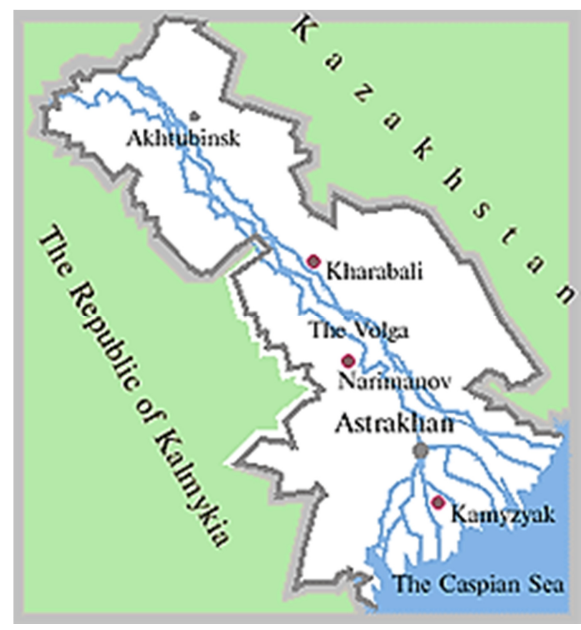

Fig. 1 Map of the Astrakhan region

A large number of ilmens - shallow lakes, located in the delta. Their distribution in the delta is uneven. Ilmens occupy about $31 \%\left(5907 \mathrm{~km}^{2}\right)$ in the western part of the delta, and $14 \%\left(2644 \mathrm{~km}^{2}\right)$ in the eastern part.

The length of ilmens varies from several hundred meters to several kilometers. The longest is the Bolshoi Beshkul ilmen $-10 \mathrm{~km}$. The width of ilmens is from 150 to $1000 \mathrm{~m}$, the depth in the low water is $-0.5-1 \mathrm{~m}$, and in the flood $-2-3.5 \mathrm{~m}$. 60 settlements with a total population of about 120 thousand are located in the zone of western steppe ilmens.

Previously, these reservoirs were replenished due to heavy floods. In recent years, according to experts, during the flood period, ilmens are flooded within a small area, which leads to their shallowing and a decrease in water quality indicators, however, they continue to serve as a water source for the population and agriculture.

The population of the Astrakhan region is 1,005,241 thousand people, of which the urban population is 660,898 thousand people, the rural population is 344,343 thousand. According to this indicator and population density (22.7 people per $\mathrm{km} 2$ ), the region takes 7 th place in the Volga region and in terms of urbanization - 6th place in the Volga region (the proportion of urban population is 67.7\%). In the Astrakhan region, 2 urban districts, 4 cities, 7 urban-type workers' settlements, 153 rural settlements, 442 settlements are registered.

The population is distributed unevenly throughout the territory, concentrating along the natural meridional axis of the territory - the Volga-Akhtuba floodplain. Moreover, almost all settlements are localized near watercourses, as a result of which the population density drops sharply with distance from them. So the zone of Western steppe ilmen is the most populated, more than 120 thousand people live in it. To ensure their water supply, 8 tracts were built (Table 1).

Currently, there are Beshkul, Prikaspiysky, Vostochnensky, Kamyshevsky, Zarechensky, Limanskiy waterways, Olya-Caspian and Tropishikinsky canals in the zone of Western steppe ilmeni. The paths are morphologically represented by ilmen connected by dug channels. Ilmeni in the tract perform a dual function: the role of a water conduit and a water reservoir. The depth of the channels is 1.5-3 m. All tracts have forced water supply from the Volga and Bakhtemir. The water in the tracts is fresh, but its mineralization gradually rises from east to west. At the end of the tracts there is a waste ilmen-evaporator. Water in the tract is exchanged 2-3 times a year. Such a high flow rate should be created in order to supply distant settlements with fresh drinking water. However, at present, the water 
exchange in the tracts is slowed down due to poor-quality operation of the cascade of pumping stations and the low-water flood established in recent years.

Table 1. Morphometric characteristics of waterways (according to Sokolsky)

\begin{tabular}{|c|c|c|c|c|}
\hline Path name & $\begin{array}{c}\text { Name of } \\
\text { branches }\end{array}$ & Power source & $\begin{array}{c}\text { Length } \\
\mathrm{Km}\end{array}$ & $\begin{array}{c}\text { Water } \\
\text { consumption } \\
\mathrm{m}^{3} / \mathrm{s}\end{array}$ \\
\hline Beshkul & - & Volga & 219,6 & 12 \\
\hline Caspian & - & $\begin{array}{c}\text { er Kisinskaya } \\
\text { Yama }\end{array}$ & 111,5 & 15 \\
\hline East & - & Khurdun River & 72 & 11 \\
\hline Kamyshevsky & $\begin{array}{c}\text { Mikhailovsky, } \\
\text { Khartsuginsky, } \\
\text { Kamyshovo- } \\
\text { Karavaninsky }\end{array}$ & Bakhtemir River & 55 & 14 \\
\hline Zarechensky & - & Bakhtemir River & 55 & 8 \\
\hline Limansky & $\begin{array}{c}\text { BLK-1,2,3 } \\
\text { Chernozemsky, } \\
\text { Yandyko- } \\
\text { Promyslovsky, } \\
\text { Stepnoy }\end{array}$ & Bakhtemir River & 213 & 27 \\
\hline Olya-Caspian & - & Bakhtemir River & 22,2 & 0,2 \\
\hline Tropishkinsky & - & Zaburunny & 9,6 & 11 \\
\hline
\end{tabular}

Currently, there are Beshkul, Prikaspiysky, Vostochnensky, Kamyshevsky, Zarechensky, Limanskiy waterways, Olya-Caspian and Tropishikinsky canals in the zone of Western steppe ilmeni. The paths are morphologically represented by ilmen connected by dug channels. Ilmeni in the tract perform a dual function: the role of a water conduit and a water reservoir. The depth of the channels is $1.5-3 \mathrm{~m}$. All tracts have forced water supply from the Volga and Bakhtemir. The water in the tracts is fresh, but its mineralization gradually rises from east to west. At the end of the tracts there is a waste ilmen-evaporator. Water in the tract is exchanged 2-3 times a year. Such a high flow rate should be created in order to supply distant settlements with fresh drinking water. However, at present, the water exchange in the tracts is slowed down due to poor-quality operation of the cascade of pumping stations and the low-water flood established in recent years.

According to modern concepts, the main negative effect of water on health is due precisely to the presence of harmful impurities of a chemical and biological nature in it. Excess or deficiency of many chemicals, natural toxins present in water have a negative effect on health. Biological factors are characterized by the presence of pathogenic bacteria, viruses and protozoa in the water

Anthropogenic eutrophication of water bodies resulting from human economic activity is accompanied by excessive development of phytoplankton [2,3]. To a certain degree of quantitative development, phytoplankton plays a positive role in the reservoir, contributing to its self-purification. However, with the increased intake of biogenic and organic substances into the body of water and the continued development of algae, there comes a moment when the development takes on the character of "blooming" water, in which the algae become a factor of self-pollution of the water body.

The massive development of algae can worsen the organoleptic characteristics of water, increase turbidity, change the chemical composition of water, and cause mechanical damage to water treatment systems, thereby having a harmful effect on human health. Therefore, when choosing a source of water supply and its further operation, it is necessary to periodically conduct a hydrobiological analysis of not only the source of water supply but the entire water supply system as a whole. 
The species composition of living organisms from the polluted reservoir serves as the final characteristic of the toxicological properties of the aquatic environment for a certain period of time and does not give its assessment at the time of the study.

During the operation of treatment facilities carrying out the withdrawal and purification of surface river waters for further operation, a certain emergency may occur.

Reproduction of microorganisms that have fallen into the sump of treatment facilities under optimal living conditions (ambient temperature, oxygen saturation, etc.) can reach a critical point. The result of this situation will be the clogging of subsequent filtration components of the treatment plant, and a decrease in filter capacity.

\section{Materials and research methods}

The biological method for assessing the state of a reservoir allows solving problems whose solution using hydrophysical and hydrochemical methods is impossible. Bioindication provides for the identification of past or ongoing environmental pollution by the functional characteristics of individuals and the environmental characteristics of communities of organisms. Gradual changes in the species composition are formed as a result of prolonged poisoning of the reservoir, and they become apparent in the case of far-reaching changes.

Thus, the species composition of living organisms from the polluted reservoir serves as the final characteristic of the toxicological properties of the aquatic environment for a certain period of time and does not give its assessment at the time of the study.

In contrast to laboratory toxicological tests, the methods for assessing the ecological state of a water source are oriented toward studying the communities of organisms in natural ecosystems and make it possible to assess their state using a whole complex of biotic indicators, which are jointly influenced by all components of the corresponding geocenosis.

Bioindication in natural communities often provides the only opportunity to obtain information about the influence of environmental parameters and their interaction. Such parameters include not only concentrations of chemicals, but also climatic conditions, transport rates of substances in the water or air environment, erosion processes in the soil, water salinity, and other indicators. From the point of view of environmental regulation of environmental factors, this approach to indication seems to be the most justified, so as suggests taking into account the response of a real multi-species community to a real multicomponent load.

The objects of research in 2019 were water samples from the surface water bodies of the Volga River in the southern reaches near water intake facilities at water treatment facilities. The first sample was taken at a distance of about 25-30 m from the coast from the thickness of the surface horizon $(0-0.5 \mathrm{~m})$, the second from a depth of $2.5 \mathrm{~m}$.

Sample preparation and analysis of phytoplankton was carried out by classical (traditional) methods [5].

\section{Research results}

According to the Federal Service for Supervision of Natural Resources Management in the Astrakhan Region, the water quality of reservoirs used for drinking water supply (category I) and for recreation (category II), according to the sanitary condition over the last 10 years of the year (2007-2017), it remains unsatisfactory.

Information on the proportion of water samples of water bodies that do not meet hygienic standards for sanitary-chemical and microbiological indicators are presented in table 2 . 
Table 2. The proportion of water samples of water bodies that do not meet hygienic standards for sanitary-chemical and microbiological indicators

\begin{tabular}{|c|c|c|c|c|c|c|c|c|}
\hline $\begin{array}{c}\text { Water } \\
\text { Category }\end{array}$ & $\begin{array}{c}\text { Proportion of water samples unsatisfactory } \\
\text { in terms of sanitary and chemical } \\
\text { indicators, }\end{array}$ & $\begin{array}{c}\text { Proportion of water samples unsatisfactory } \\
\text { in microbiological indicators, } \%\end{array}$ \\
\cline { 2 - 9 } & 2016 & 2017 & 2018 & $\begin{array}{c}\text { dynamics by } \\
2019\end{array}$ & 2016 & 2017 & 2018 & dynamics by 2019 \\
& 3,86 & 5,83 & 1,7 & $\downarrow$ & 5,17 & 0,96 & 0,8 & $\downarrow$ \\
\hline I & 1,91 & 0,13 & 2,1 & $\uparrow$ & 16,10 & 10,11 & 1,8 & $\downarrow$ \\
\hline II & & & & & & & \\
\hline
\end{tabular}

In 2018, compared with 2017, there is an improvement in the state of water bodies in places of water use of the population used as drinking water supply (category I) by sanitary and chemical indicators - by $4.13 \%$, by the microbiological indicators, the proportion of unsatisfactory samples continues to decrease $0.16 \%$.

Microbiological indicators. The total number of microorganisms in the surface and deep horizons of sampling is $10^{6}-10^{8}$ cells $/ \mathrm{ml}$ (table 3 ), the average number of oligotrophic ones exceeds the number of eutrophic ones by 2-3 times.

Table 3. Microbiological parameters of the investigated water

\begin{tabular}{|c|c|c|c|c|c|}
\hline Sampling Place & $\begin{array}{c}\text { Total number } \\
\text { of bacteria, } \\
\text { cells/ml (Ne) }\end{array}$ & $\begin{array}{c}\text { Total } \\
\text { microbial } \\
\text { number of } \\
\text { eutrophic } \\
\text { bacteria, } \\
\text { CFU/ml } \\
\text { (N0) }\end{array}$ & $\begin{array}{c}\text { Oligotrophic } \\
\text { bacteria, CFU/ml } \\
\text { (Ntnb) }\end{array}$ & $\begin{array}{c}\mathrm{Kn}= \\
\mathrm{Ne}+\mathrm{N} 0 \\
\mathrm{Ntnb}\end{array}$ & $\begin{array}{c}\text { Common } \\
\text { coliform } \\
\text { bacteria, } \\
\text { CFU/ml }\end{array}$ \\
\hline Surface layer & $0,3 * 10^{8}$ & $1,3 * 10^{4}$ & $2,8 * 104$ & 0,0014 & - \\
\hline Deep layer & $0,9 * 10^{6}$ & $0,8^{*} 10^{4}$ & $2,3 * 104$ & 0,034 & - \\
\hline
\end{tabular}

The results obtained, characterizing the small predominance of oligotrophic microflora over eutrophic, make it possible to assert that in the reservoir there is a low concentration of easily decomposable organics. A similar pattern is often observed in open waters of the seas and with a seasonal decrease in water temperature.

A similar indicator of the state of the microbial ecosystem at different time periods can be the ratio of the number of heterotrophic bacteria capable of growth on nutrient media to the total number of bacteria recorded by direct microscopy. This indicator was first proposed by the Russian microbiologist A.S. Razumov (1932) to assess the degree of trophy of freshwater bodies and was called the Razumov coefficient (Ki). A high Ki index indicates a high rate of multiplication of heterotrophic bacteria, which occurs with an abundance of labile organic matter in the aquatic environment. After its exhaustion, the bacteria go into a state of starvation, the rate of their reproduction decreases, which corresponds to low values of Ki: In our case, the Ki coefficient is quite low (0.03-0.0014), which allows us to classify the studied waters as oligotrophic.

Coliform bacteria were not detected in any of the samples.

Phytoplankton of the studied water samples. Phytoplankton of the studied area of the river. The Volga, were representatives of algae groups - green, diatoms, cyanobacteria. The numerical characteristics of the algae found in the samples are presented in Table 4.

The observed period of 2019 was characterized by high air temperatures. Accordingly, the water temperature in the watercourses of the Astrakhan region was higher than in previous years. It was previously established that the activity of the sun is a determining factor in the intensity of development of blue-green (cyanobacteria) - the causative agents 
of "blooming" water, but the concentration and biomass of phytoplankton in years of low activity are characterized by higher rates.

Table 4. Phytoplankton of the Volga River in the study area.

\begin{tabular}{|c|c|c|}
\hline Name of phytoplankton & \multicolumn{2}{|c|}{ Quantitative indicators of phytoplankton, $\frac{\text { million cells } / \mathrm{m} 3}{\text { biomass } \mathrm{mg} / \mathrm{m} 3}$} \\
\cline { 2 - 3 } & Surface horizon & From a depth of $2.5 \mathrm{~m}$ \\
\hline Green & $\frac{670}{97,2}$ & $\frac{532}{126,8}$ \\
\hline Diatoms & $\frac{2710}{5675,9}$ & $\frac{3080}{2596,5}$ \\
\hline Cyanobacteria & $\frac{17035}{206,7}$ & $\frac{60300}{222,2}$ \\
\hline Total & $\frac{20415}{5979,8}$ & $\frac{63912}{2945,5}$ \\
\hline Number of taxa & 29 & 35 \\
\hline Temperature, $t,{ }^{\circ} \mathrm{C}$ & 27 & 27 \\
\hline
\end{tabular}

In the phytoplankton community of the surface horizon of the Volga River, 29 taxa of algae were found in the study area. Of these, 13 taxa were green (Chlorophyceae), 8 diatoms (Bacillariophyceae) and 3 - cyanobacteria (or blue-green (Cyanophyceae) algae. The first place in phytoplankton in biomass belonged to diatoms, constituting 5675,86 $\mathrm{mg} / \mathrm{m}^{3}(94,91 \%)$, among them the algae of the genus Melosira provided $92.75 \%$ of the total biomass (M. granulana - 53,59; M varians - 39,16\%).

Cyanobacteria ranked second in biomass $-206,72 \mathrm{mg} / \mathrm{m}^{3}(3,46 \%)$. According to the total number of phytoplankton, cyanobacteria prevailed, providing 17035 million cells $/ \mathrm{m} 3$ $(83,45 \%)$, of which $66.13 \%$ of the population was small-cell (its diameter is 1.5 microns) colonial Mycrocystis pulverea (13500 million cells $/ \mathrm{m}^{3}$ ) and 15,95\% - on filamentous cyanobacteria of the genus Oscillatoria (O. subtillissima -10,07; O. limnetica- 4,58; O. irrigua $-1,30 \%)$. The next were diatoms, their number was 2710 million cells $/ \mathrm{m}^{3}(13,27$ $\%)$. The total biomass and abundance of green algae were $97.18 \mathrm{mg} / \mathrm{m}^{3}(1.63 \%)$ and 670 million cells $/ \mathrm{m} 3(3.28 \%)$.

The phytoplankton of the Volga River at a depth of $2.5 \mathrm{~m}$, in the area of water intake in the study area, is represented by 35 algae taxa, including 12 green, 13 diatoms and 10 cyanobacteria taxa. The trend of the prevailing groups and their species has been preserved here. Only absolute values have changed. So the biomass of diatoms became two times lower due to a decrease in the size of M. granulana cells. Its diameter in the deep layer was 5 microns, in the surface horizon - 8 microns, although its number was 2772 million cells $/ \mathrm{m}^{3}$ (55.44\% of the total number of algae). The total number of cyanobacteria increased by more than 3.5 times and amounted to 60300 million cells $/ \mathrm{m} 3(9435 \%)$. The number of alga M. pulverea (Cyanobacteria) increased 4.1 times relative to the surface horizon and amounted to 55,000 million cells $/ \mathrm{m}^{3}$, which provided $86.06 \%$ of the total number of algae.

The massive development of cyanobacteria, namely M. pulverea and representatives of the genus Oscillatoria in deeper horizons, is explained by their biology. Excessive solar radiation is detrimental to algae. They have a protective mechanism against direct sunlight sink into the water column and produce a special red pigment - phycoerythrin, which is clearly visible at a magnification of 400 times in the M. pulverea algae - chromatic adaptation. Cyanobacteria can quickly switch from autotrophic to heterotrophic nutrition (mixotrophism) in poorly lit water layers. The fact of stimulation of the growth of microcystis of organic substances of water and bottom sediments, especially sludge []. Some types of cyanobacteria, including representatives of the genus Mycrocystis in massive quantities, cause harmful effects. 
To assess the pollution of a reservoir, it is also important to determine the index of species diversity of phytoplankton, which is found by the Menginik formula (1):

$$
J=S / \sqrt{n}
$$

where J- species diversity index, $\mathrm{S}$ - number of species, $\mathrm{n}$ - number of individuals. In unpolluted water bodies, the index is 12 and higher, and in polluted water it is 8 or lower. Using this formula, we calculated the degree of pollution of the studied reservoir. It is equal to 4 . Based on these data, it can be concluded that the Volga River is a highly polluted body of water.

\section{Consideration}

At urban water treatment plants in the cities of Astrakhan, Akhtubinsk, Krasny Yar, etc. with water intake from the Volga River, a musty, earthen, moldy water smell is observed in some years in the summer-autumn period. The presence of substances that add undesirable odor and taste to drinking water causes reasonable claims and complaints from consumers. The presence of these substances is most often associated with natural processes - the active growth and metabolism of organisms in the sources of drinking water. Therefore, according to studies in the summer season, the concentration of phytoplankton exceeds more than 3 times the allowable standard for sources of centralized drinking water supply (GOST 276184 ), the concentration of microalgae on some days exceeds 300,000 cells $/ \mathrm{cm}^{3}$ [1].

The presence of algae in the water source adversely affects the operation of water treatment plants. Hot climate, high temperatures, small volumes of water sources and low flow rates contribute to the active development of bacteria and the growth of algae and, as a result, the appearance of organic compounds in water in the form of various anthropogenic products of the biocenosis and dissolved organic matter - products of the decay of phytoplankton. Particularly noteworthy is the ability of cyanobacteria in the process of their life to secrete a sufficiently large group of toxic substances (microcystin, linguiatoxin, debromaplysitoxin, oscillatoxin, nodularia toxin, toxoid, afanotoxin, oscillatorium toxin), with a wide spectrum of effects on biological objects.

It is known that chlorination of water during water treatment does not affect the removal of metabolites secreted by massively developing species of cyanobacteria (blue-green algae).

On the other hand, chlorine forms an organochlorine that causes cell mutagenicity. So, for example, when ingested, they can act as initiators and promoters in the process of carcinogenesis $[5,6]$.

In addition, the cell size of various groups of cyanobacteria varies from 1 to 50 microns, that is, certain groups of algae, on the one hand, can easily penetrate through ordinary filters of waterworks and enter the network [1, 3, 4], on the other hand Remaining in the filters, an intensive growth of phytoplankton occurs, which paralyzes the operation of the filters. Additional volumes of water are required for washing structures; the number of flushing increases.

In this case, the water treatment technology should provide for the removal of odors of water. It can be achieved by coagulating and flocculating impurities, followed by filtering, but to eliminate undesirable odors and tastes inherent in the Volga water source in the summer and characterized by great resistance, the use of special technologies is required. Smells and smacks caused by organic substances are extracted by sorption, which uses activated anthracite, powdery and granular activated carbon, carbon fiber materials and non-carbon sorbents (clinoptelolite, zeolites, etc.). The sorption method is more reliable 
than the oxidative one since it is based not on the destruction of organic substances, but on their extraction from water.

\section{Conclusion}

The sanitary regime of the reservoir is characterized, first of all, by the amount of oxygen dissolved in it. It should be beaten by at least $4 \mathrm{mg}$ per 1 liter of water at any time of the year for water sources. The first type includes water bodies used for drinking water supply to enterprises, the second - used for swimming, sporting events, as well as within settlements.

Microorganisms sorbed on suspended particles moving relative to the water mass due to gravitational sedimentation of particles under the action of gravity are capable of cleansing water bodies. As a result, the water mass and microorganisms move relative to each other, which is equivalent to the situation when the water is filtered through a granular substrate with attached microorganisms; the latter extract dissolved organic matter and nutrients from the water.

The massive development of blue-green algae (cyanobacteria) in water sources under certain adverse conditions can be considered as a process of self-pollution of a water source.

The increase in the number of types of cyanobacteria and the massive development of M. pulverea (Cyanobacteria), caused by abiotic factors of 2010 (abnormally high air temperature for a long period and warming of the deep layers of water) and physiological and biochemical characteristics of cyanobacteria (isolation of various metabolites, including exotoxins) caused a deterioration in water quality (organoleptic indicators).

The analysis of the state of the water supply systems of settlements of the Astrakhan region revealed the need to introduce into practice the water supply of problem facilities in the region of facilities for removing odors and flavors and water by sorption using local sorbent materials, which will make it possible to even out the sanitary and epidemiological situation in the region.

\section{Findings}

1. From an analysis of the data of coenotic characteristics of phytoplankton, it was found that its development increased in the deep sea by 3.5-4 times, relative to the surface. This growth is due to an increase in the number of species of cyanobacteria and the massive development of M. pulverea (Cyanobacteria), caused by abiotic factors of 2019 (an abnormally high air temperature for a long period) and the biological capabilities of cyanobacteria. Mass presence of alga M. pulverea (Cyanobacteria), caused a change in water quality (organoleptic characteristics).

2. When using water rich in phytoplankton, traditional technologies and facilities for water intake and purification cannot ensure the proper quality of water consumed for domestic and drinking needs. Therefore, it is necessary to consider introducing technologies for removing odors and tastes from water.

\section{References}

1. L. V. Boronina, P. N. Sadchikov, S. Z. Tazhieva, E. V. Moskvicheva Wat. Resour. 43, 657-662. (2016) DOI: 10.1134/S0097807816040059 
2. L. A. Sirenko, T. V. Parshykova, In. V. Evangelista, L. Barsanti, A.M. Frassanito, V Passarelli, P. Gualtieri NATO Science for Peace and Security Series A: Chemistry and Biology. Springer, Dordrecht (2008) https://doi.org/10.1007/978-1-4020-8480-5_10

3. L. V. Boronina, N. Serpokrylov, S. Z. Tazhieva, Vestnik SGASU. Urb. plan. Archit. 4, 19-21. (2013) DOI: 10.17673/Vestnik.2013.S4.5

4. J. E. Adolf J.E., D. K. Stoecker, L.W. Harding J. Plankt. Rech. 28, 737-751 (2003)

5. L.Boronina, R.Israilov, V.Fomichev MATEC Web of Conferences 251 (2018) https://doi.org/10.1051/matecconf/201825103046.

6. L. Boronina, E. Davydova, A. Sokolskiy IOP Conf. Series: Materials Science and Engineering 451 (2018) doi:10.1088/1757-899X/451/1/012217.

7. L.V. Boronina, P.N. Sadchikov Bulletin of SASU. Urb. Plan. Arch.15-18. 2013 DOI: 10.17673 / Vestnik. 2013.S4.4.

8. L.V. Boronina, N.S. Serpokrylov, S.Z. Tazhieva Bulletin of SASU. Urb. Plan. Arch. 13, 19-21 (2013) DOI: 10.17673 / Vestnik.2013.S4.5.

9. A. E. Usynina, L.V Boronina, Bulletin of SASU. Urb. Plan. Arch.13, 93-95 (2013) DOI: 10.17673 / Vestnik.2013.S4.25.

10. V. A. Milyutkin, I.V Borodulin, E. A. Agarkov, G. S. Rosenberg, G.E. Kudinova Ecological problems of large river basins 6, 199-201 (2018). DOI: 10.24411 / 9999-002A2018-10084.

11. S.V. Klein, S.A. Vekovshinina, A.S. Sboev, Hygiene and sanitation 1, 10-14 (2016). DOI: 10.18821 / 0016-9900-2016-95-1-10-14.

12. L.G. Konshina, Hygiene and Sanitation 5, 413-416 (2016). DOI: 10.18821 / $0016-$ 9900-2016-95-5-413-416. 